\title{
Case Study: Belonging in Dialogue. How to Integrate Hélène Cixous and Jacques Derrida in French Literary Studies
}

It is uncontested that Hélène Cixous and Jacques Derrida are among the most important thinkers of French expression in the twentieth century. Due to the complexity and vast scope of their writings, it is, however, rare to find their texts in French Studies curricula in German universites.

Nonetheless, these oeuvres contain texts that, due to their brevity and composition, are not only highly suitable for academic education, but also address fundamental issues of our time such as displacement, migration and belonging and their representation in language.

This contribution aims to illustrate this by means of two essays. First, Mon Algériance by Hélène Cixous, a short essay that was first published 1997 in Les Inrockuptibles, a journal explicitly dedicated to participating in the public sphere. ${ }^{1}$ The second text is L'anti-Macias : Moi, l'Algérien by Jacques Derrida, published in 2003 in Le Matin. ${ }^{2}$

1 This essay by Cixous was first published as a contribution in the parlement international des écrivains of the series littérature déplacée in the cultural magazine Les Inrockuptibles 115 (1997): 71-74; the English revised translation first appeared in the literary magazine TriQuarterly of Northwestern University, Evanston: TriQuarterly 100 (1997): 259-279. Later it was published as one of ten essays in: Cixous, Hélène, "My Algeriance. In other words: to depart not to arrive" (Cixous 1998, 203-231). This revised translation comprises an additional paragraph entitled "Shoeshine": 221-3. The paraghraph entitled "The Name of Cixous" is extended by further considerations: "My house is encircled", "Do you remember Cinna the poet?", "The illegitimate" and "'The legitimiate”" (My Algeriance: 211-218, cf. Mon Algériance: 72-73). The chapter "Impressions, im-prints, mirrors" comprises considerations to binary thought in "my aunts shop Aux deux mondes, The Two Worlds”, (My Algeriance: 219-21, cf. Mon Algériance: 73-74). These additional elements can also be found in Pieds nus (Cixous 1997b: 60).

2 In a first part, the essay is structured by three starting points of reflections and marked by the colons after them, "Mes héritages :” , "L’arabe, langue interdite :” and "Foi et savoir :”. In a kind of second part, separated from the first part by two asterisks, there is a further development of the reflection on religion and faith: a foi universelle as the basis of every ,adresse de parole' as a common place of people and as an opportunity for social questions concerning secularity and religion in France. This version appeared posthumously in the newspaper Le Matin. Derrida, Jacques. "L’Anti-Macias : Moi, l’Algérien de Jacques Derrida”, Le Matin, 21.11.2007. Hereinafter: “Moi, l’Algérien”. The essay comprises selected extracts from a conversation between Mustapha Chérif and Jacques Derrida as closing talk “Algérie-France, Hommage aux grandes figures du

Ә OpenAccess. (C) 2020 Sara Sohrabi, published by De Gruyter. (cc) BY-NC-ND This work is licensed under the Creative Commons Attribution-NonCommercial-NoDerivatives 4.0 License.

https://doi.org/10.1515/9783110619003-016 
Both texts reflect Jewish historical experiences of the twentieth century in a post-essentialist perspective that can prove extremely fruitful in the context of traditional French philology. They also pursue their reflections in the French language itself, thus performing a de-nationalization of the French language.

At the same time, the integration of Jewish historical experience is epistemologically universalized, and addresses the colonial remnants engraved in the French language, amongst other essentialisms.

Marked by the dialogical profile of the respective mode of thinking and writing, both essays deal with historical experiences in a specific way. My thesis is that Derrida's and Cixous' philosophical approaches to historical experiences through language can be described as a hinge position between different memories, one which makes the tectonic layers visible that compose French-Algerian memory. ${ }^{3}$ Through this linguistic-philosophical procedure, it becomes evident how historical experiences were an impetus for their writing. ${ }^{4}$ It is in this sense that these aesthetic, literary and philosophical texts became modes of universal critique. ${ }^{5}$

The different oeuvres of Cixous and Derrida converge in their questioning of identitarian assumptions about language, literature, and historical experiences. It is against this backdrop that the connections between these two eminent figures of French intellectual history, whose writings are mostly affiliated with the categories of poststructuralism, French feminism and psychoanalysis, are to be understood. ${ }^{6}$ However, if we contextualize their works historically, they appear closely linked to historical events in and beyond Europe since the nineteenth century, to the Algerian experience, and their collective memories:

Ma pensée est née avec la pensée que j'aurais pu naître ailleurs, dans un des vingt pays où avait atterri un éclat vivant de ma famille maternelle qui avait sauté sur le champ de mines nazi. Avec la pensée du hasard, de l'accident, de la chute. La pluie d'atomes de Lucrèce, en

dialogue des civilisations" on the occasion of a conference colloquium organised by Chérif in 2003 as part of the series "Dialogue des civilisations". The closing talk took place on 27 Mai 2003 at the Institut du monde arabe, Paris. As far as the rhetorical dressing of the text is concerned, the "vous" addresses the interlocutor Chérif, (Chérif 2006). An English (Chicago: University of Chicago Press, 2008) and a German Version were published subsequently (Paderborn: Fink, 2009).

3 Cf. (Diner 2007, 64-67).

4 Cf. (Zepp and Gordinsky 2009, 102-103).

5 Cf. (Stevens 2002, 77-79).

6 For a critical summary of research on and reviews of the oeuvres of Cixous and Derrida in research cf. (Christopher 2001, 79-84). 
pleuvant l'atome de ma mère avait rencontré l'atome de mon père. La molécule étrange détachée de la nue noire de Nord avait atterri en Afrique. (Cixous 1997a, 71) ${ }^{7}$

For the speaker in the text Mon Algériance, the Algerian experience, broadly described as exile, does not assume the role of a rupture requiring substitution or replacement. She represents her own experience of leaving and the related questions that she associates with places in general and Algeria in particular, not as a "lack of" or as a "less". From the speaker's perspective, such negative connotations are redundant; she intends to free herself from a premise of national belonging and to open a much broader space. She speaks of the experience of belonging to the world, in which national ideas and constructs and thus also essentialist ideas of identities dissolve, that before had set her in a "double bind" (Cixous 1997a, 72). ${ }^{8}$ She therefore perceives her existence as one of a passante de l'histoire:

Mon histoire est prise entre une double mémoire contradictoire :

- d'un côté ma famille allemande installée à Strasbourg au début du XX $\mathrm{X}^{\mathrm{e}}$ siècle s'est vu octroyer par la France victorieuse de 1918 une nationalité française qui alors ne la retint pas de rentrer précipitamment "chez elle" en Allemagne et qui par la suite s'avéra salutaire pour ma mère et ma grand-mère, lorsque la mort devint le maître de l'Allemagne comme dit Celan :

- de l'autre côté la même France si c'est la même - dont le geste de 1918 sauvait in extremis ma grand-mère en 1938 - nous jetait en 1940 hors de la citoyenneté française et nous privait de tous les droits civils, à commencer pour moi par celui d'aller à l'école, et pour mon père celui d'exercer la médicine qu'il venait pourtant en 1939 d'exercer sur le front tunisien dans l'armée française.

Ni la France, ni l'Allemagne, ni l'Algérie. Pas de regret. C'est une chance. Une liberté, une liberté incommode, intenable, une liberté qui oblige à lâcher prise, à s'élever, à battre des ailes. A tisser un tapis volant. Je ne me suis trouvée bien nulle part. (Cixous 1997a, 72) ${ }^{9}$

7 "My way of thinking was born with the thought that I could have been born elsewhere, in one of the twenty countries where a living fragment of my maternal family had landed after it blew up on the Nazi minefield. With the thought of the chanciness, of the accidence, of the fall. Lucretius's Rain of atoms, in raining, the atom of my mother had met the atom of my father. The strange molecule detached from the black skies of the north had landed in Africa." (Cixous 1998, 126)

8 "les paradoxes de ce passeport [...]: l'avoir m'enferma toujours dans un double bind" (Cixous 1997a, 72).

9 "My history is held between a double contradictory memory: - on one hand my German family which moved to German Strasbourg at the beginning of the twentieth century was granted French nationality by a France victorious in 1918, yet this did not keep the family from returning 
It is striking how Cixous de-nationalizes here the iconic French concept of liberty. To not belong to either France, Germany or Algeria is described as a liberty that is profound and full of opportunity.

Derrida's parallel reflection is marked as well by an awareness of the specific scope and existence of the categorical constraint that emanates from a binary thought system: ${ }^{10}$

L'héritage que j'ai reçu de l'Algérie est quelque chose qui a probablement inspiré mon travail philosophique. Tout le travail que j'ai poursuivi, à l'égard de la pensée philosophique européenne, occidentale, comme on dit, gréco-européenne, les questions que j'ai été amené à lui poser depuis une certaine marge, une certaine extériorité, n'auraient certainement pas été possibles si, dans mon histoire personnelle, je n'avais pas été une sorte d'enfant de la marge de l'Europe, un enfant de la Méditerranée, qui n'était ni simplement français ni simplement africain, et qui a passé son temps à voyager d'une culture à l'autre et à nourrir les questions qu'il se posait à partir de cette instabilité. (Derrida 2007) ${ }^{11}$

The text stresses the important cognitive value of being "in-between": being neither one nor the other. From this only seemingly unstable situation can emerge epistemological questions that mark Derrida's philosophical work as a whole:

Tout ce qui m’a intéressé depuis longtemps, au titre de l'écriture, de la trace, de la déconstruction de la métaphysique occidentale - que je n'ai jamais quoi qu'on en ait répété, identifiée comme une chose homogène ou définie au singulier , tout cela n’a pas pu ne pas pro-

\footnotetext{
hastily 'home' to Germany and it subsequently turned out to be salutary for my mother and my grandmother, when death became the master of Germany, as Celan says. - on the other hand the same France, if it is the same - which saved my German grandmother at the last minute in 1938 by its gesture of 1918 - threw us out of French citizenship in 1940 in Algeria and deprived us of all civil rights, beginning for my brother and me with the right to go to school, and for my father to practice medicine which he had just practiced in 1939 as a lieutenant on the Tunisian front in the French Army. Neither France, nor Germany nor Algeria. No regrets. It is good fortune. Freedom, an inconvenient, intolerable freedom, a freedom that obliges one to let go, to rise above, to beat one's wings. To weave a flying carpet. I felt perfectly at home, nowhere" (Cixous 1998, 127128).

10 Amongst many, I here recommend the encyclopedic entry "Deconstruction" by Eric Prenowitz in Encyclopedia of Jewish History and Culture (Prenowitz 2018, 81-87).

11 "The cultural heritage I received from Algeria is something that probably inspired my philosophical work. All the work I have pursued, with regard to European, Western, so-called GrecoEuropean philosophical thought, the questions I have been led to ask from some distance, a certain exteriority, would certainly not have been possible if, in my personal history, I had not been a sort of child in the margins of Europe, a child of the Mediterranean, who was not simply French nor simply African, and who had passed his time traveling between one culture and the other feeding questions he asked himself out of that instability" (Chérif 2006, 31-33).
} 
céder de cette référence à un ailleurs dont le lieu et la langue m'étaient pourtant inconnus ou interdits. (Derrida 2007) ${ }^{12}$

Describing his own writing as "la trace, la déconstruction de la métaphysique occidentale" is also an answer to critique: from the position of the in-between, it is quite logical that the field of interest is not homogeneous. ${ }^{13}$

In a similar move, Cixous further describes the experience of partir as crucial for these epistemological constellations:

Quand j'ai eus 3 ans, l'âge des expériences décisives et de l'analyse, je sus que j'étais destinée de partir. Certes ce serait plus tard, mais ce serait au plus tôt. Cette destination, destinalité, décision était si forte que j'ai pu dire : quand j'avais 3 ans je suis partie. C'était un pur partir. Je n'avais pas de visée ou de vision d'arrivée, de but, pas de pays désiré, j'étais en sursis et en survol. En détachement quasi originel. (Cixous 1997a, 73) ${ }^{14}$

The essay is emphasizing the experience of leaving without a goal or the need to arrive - "partir (pour) ne pas arriver d'Algérie" (Cixous 1997, 74). In this way, the speaker establishes a perspective that cannot be reduced to a binary logic. Such a conception of belonging surpasses any state of exile:

Ma propre famille maternelle, l'allemande, s'était déjà détachée de ses sols (Strasbourg, Budapest, Osnabrück, Bratislava, etc.). La possibilité de vivre sans enracinement m'était familière. Je n'appelle jamais cela exil. Certains réagissent à l'expulsion par le besoin d'appartenir. Pour moi, comme pour ma mère, le monde me suffisait, je n'eus jamais besoin d'un pays terrestre, localisé. (Il reste dans le mode d'habitation familiale une sorte de dépouillement de nomade : jamais de meubles. Toujours le sac à dos.) (Cixous 1997a, 73) ${ }^{15}$

12 "Everything that has interested me for a long time, regarding writing, the trace, the deconstruction of Western metaphysics - which, despite what has been said, I have never identified as something homogeneous or defined in the singular (I have so often explicitly said the contrary)all of that had to have come out of a reference to an elsewhere whose place and language were unknown or forbidden to me" (Chérif 2006, 33-35).

13 On the concept of trace in Derrida's thinking cf. Bennington 1994, 229-230.

14 "When I was three, the age of decisive experiences and of analysis, I knew that I was destined to leave. Of course it would be later on, but it would be as soon as possible. That destination, destinality, decision, was so strong that I have been able to say: when I was three I left. It was pure departure. I had no aim or vision of an arrival, no goal, no desired country, I was in deferment and flight. In quasi-original detachment" (Cixous 1998, 137).

15 "My own maternal family, the German one, had already detached itself from its earth (Strasbourg, Budapest, Osnabrück, Bratislava, etc.). The possibility of living without taking root was familiar to me. I never call that exile. Some people react to expulsion with the need to belong. For me, as for my mother, the world sufficed, I never needed a terrestrial, localized country. (In the family mode of dwelling there remained a nomad'ssimplicity: never any furniture. Always the backpack.)" (Cixous 1998, 137). 
In Cixous essay, all elements of thought attest to a reflection or a course of argumentation that are derived from engagement with the French language itself, the neologism in the title Mon Algériance being the first of many linguistic subversions of standard French.

In both essays, historical references open up multiple levels of meaning, multifold linguistic experiments and their implications. Thus, language is being performed as the subject: through double, multiple, and even contradictory linguistic meanings, thoughts can be presented that dismantle and rebuild meaning, to emphasize what proves to be a fundamental intellectual challenge:

J'avais la langue et ses sousterrains.

Ou plutôt j'avais: Mes langues.

Je l'ai souvent raconté, on jouait aux langues chez nous, mes parents passant avec plaisir et adresse d'une langue à l'autre tous les deux, l'un depuis le francais l'autre depuis l'allemand, en sautant par l'espagnol et l'anglais, l'un avec un peu d'arabe et l'autre avec un peu d'hébreu. (Cixous 1997a, 73) ${ }^{16}$

The contact with many different languages has had an effect on the French language that is valued very highly. The speaker denies that there exists one privileged relationship to one language, a so-called mother tongue: She never submitted herself to such notions of obedience and obligation of a single language. For Cixous, German, French, English, Spanish, Arabic and Hebrew were not only the languages in which she grew up:

Cette agilité, ce sport translinguistique et amoureux m’abrita de toute obligation ou velléité d'obédience (Je ne pensai pas que le français fût ma langue maternelle, c'était une langue dans laquelle mon père m’apprenait) à une langue materpaternelle. (Cixous 1997a, 73) ${ }^{17}$

Cixous also distinguishes between her mother's several languages and those of her father to highlight the dialectics of historical experience in her family. During the colonial period in Algeria, the Arabic and Hebrew languages stood for historically marginalized and antagonized communities. The Arabic language in par-

16 "I had the language and its subterranean passages. Or rather I had: My languages. We played at languages in our house, my parents passed with pleasure and deftness from one language to the other, the two of them, one from French the other from German, jumping through Spanish and English, one with a bit of Arabic and the other with a bit of Hebrew. When I was ten years old my father gave me at the same time an Arabic teacher and a Hebrew teacher" (Cixous 1998, 137).

17 "That translinguistic and loving sport sheltered me from all obligation or vague desire of obedience (I did not think that French was my mother tongue, it was a language in which my father taught me) to one mother-father tongue" (Cixous 1998, 138). 
ticular was violently suppressed by the colonial powers in Algeria's administration and public life:

Nous vécûmes toujours dans les épisodes d'une Algériade brutale, jetés dès la naissance dans un des camps grossièrement façonnés par le démon de la Colonialité. On disait : "les Arabes”, "les Français”. Et on était joués de force dans la pièce, sous une fausse identité [...] Mes langues glissaient l'une dans l'autre oreille d'un continent à l'autre. Longtemps j'assurai - mais je n'y croyais pas - que ma langue maternelle était l'allemand - mais c'était pour conjurer le primat de la langue française, et parce que l'allemand à jamais éloigné de la bouche de ma conscience par l'épisode nazi, était devenue la langue idéalisable de ma parenté morte. Ces circonstances excluantes firent que la française comme l'allemande me parurent toujours venues à moi charmantes comme la fiancée étrangère. Mais à l'école je voulus toujours être la meilleure "en français" comme on disait pour honorer mon père, le chassé. (Cixous 1997a, 72-73) ${ }^{18}$

In Derrida's essay, the Arabic language and the history of Algeria before 1830 in the context of the colonial system are used to address the violence of oppression against Algerian cultures. Derrida emphasizes that the Arabic language had assumed an existential significance for him. It had become a counterpoint, an alternative with regard to French humiliations. The memory of this language evokes Derrida's childhood and youth in Algeria. Arabic was not allowed to be spoken in schools:

L'arabe, langue interdite : la langue arabe, cet ailleurs, m'était comme inconnue ou interdite par l'ordre établi. Un interdit s'exerçait sur la langue arabe. Il prit bien des formes culturelles et sociales pour quelqu'un de ma génération. Mais ce fut d'abord une chose scolaire, un dispositif pédagogique. L'interdit procédait d'un "système éducatif", comme on dit en France. Vu les censures coloniales et les cloisons sociales, les racines, étant donné la disparition de l'arabe comme langue officielle, quotidienne et administrative, le seul recours pour l'apprentissage de l'arabe était l'école, mais au titre de langue étrangère ; de

18 "We always lived in the episodes of a brutal Algeriad, thrown from birth into one of the camps crudely fashioned by the demon of Coloniality. One said: 'the Arabs'; 'the French.' And one was forcibly played in the play, with a false identity. [...] My languages slid into each other's ear from one continent to another. For a long time I asserted - but I did not believe it - that my mother tongue was German - but it was to ward off the primacy of French, and because German, forever distanced from the mouth of my conscience by the Nazi episode, had become the idealizable language of my dead kin. These excluding circumstances made French and German always seem to be coming to me charming like the foreign fiancée. But at school I always wanted to beat the French in French, to be the best 'in French' as they said, to honor my father, who had been driven out." (Cixous 1998, 128 and 138) 
cette étrange sorte de langue étrangère comme langue de l'autre, certes, quoique, voilà l'étrange et l'inquiétude, de l'autre comme le prochain le plus proche. (Derrida 2007) ${ }^{19}$

\title{
Derrida describes the historical experiences of the Algerian-Jewish community as
} a position between contested memories:

\begin{abstract}
Mes héritages : je voudrais parler comme Algérien, né juif d'Algérie, de cette partie de la communauté qui avait reçu en 1870, du décret Crémieux, la nationalité française et l'avait perdue en 1940. Quand j'avais 10 ans, j'ai perdu la citoyenneté française au moment du régime de Vichy et pendant quelques années, exclu de l'école française, j’ai fait partie de ce qu'on appelait, à ce moment-là, les juifs indigènes, qui ont rencontré parmi les Algériens de l'époque plus de solidarité que de la part de ce qu'on appelait les Français d'Algérie. C'est l'un des tremblements de terre de mon existence. Il y en a eu d'autres. (Derrida 2007) ${ }^{20}$
\end{abstract}

Derrida's essay does not want to be understood as a definition of colonial structures. Rather, the text is an example of what it means to write philosophically about the consequences of colonial experience. These perspectives are all the more important because the social and cultural consequences of the historical experiences and wars of the twentieth century so plainly mark today's time and today's Europe.

In this respect, both essays share a common political claim, realized in the demand for the right not to belong in an identitarian thought system. Hélène Cixous and Jacques Derridas' writings elude the logic of binary systems and orders. The experience of non- or multiple affiliations opens up perspectives that, in

19 "The Arab language, that other, was unknown or forbidden to me by the established order. A ban was placed on the Arab language. The ban took on many cultural and social forms for someone of my generation. But it was above all a school issue, something that happened at school, a pedagogical matter. The ban came out of an 'educational system', as we say in France. Given the colonial censures and the social barriers, the various forms of racism, given the disappearance of Arabic as a daily, official, and administrative language, the only way to learn Arabic was at school, but as a foreign language; as that strange sort of foreign language that is the language of the other, although - and this is what is strange and disturbing - of another who was the closest of the close." (Chérif 2006, 33-35)

20 "My heritages: I would like to speak today as an Algerian. I was born a Jew in Algeria, from that part of the community which in 1870 had obtained nationality through the Cremieux Decree, and then lost it in 1940. When I was ten years old, during the Vichy regime, I lost my French citizenship, and for a few years, unable to attend the French school, I was a member of what at the time was called the native Jews, who during those times experienced more support from the Algerians than from what were known as the Algerian French. That was one of the earth-shattering experiences of my existence, one of the earth-shattering Algerian experiences of my existence. There have been others" (Chérif 2006, 29). 
times of new nationalisms, are worth turning to - also for matters beyond literary questions.

Thus, the integration of these two texts into the corpus of French Studies allows not exclusively conveying Jewish historical experience. The two texts also offer a variety of opportunities for critical reflection on French colonial history between language policy, citizenship and violence. Moreover, the texts can also enable a discussion of the transformations of the key concepts of the French Revolution (freedom, equality, fraternity) in the light of France's history in the twentieth century.

\section{Bibliography}

Bennington, Geoffrey. Legislations: The Politics of Decontruction, London: Verso, 1994.

Chérif, Mustapha. L'Islam et l'Occident. Rencontre avec Jacques Derrida, Paris: Odile Jacob, 2006.

Churchill, Christopher. L'Algérie en 'je': Remembering Colonial Algeria in the Works of Hélène Cixous and Jacques Derrida. Ontario: Queens University, 2001.

Cixous, Hélène. "Mon Algériance." Les Inrockuptibles 115 (1997): 70-74.

Cixous, Hélène. “My Algeriance.” Stigmata. Escaping Texts. Oxfordshire: Routledge, 1998. 203-231.

Cixous, Hélène. "Pieds nus” Une enfance algérienne. Textes inédits recueillis par Leïla Sebbar. Ed. Leila Sebbar. Paris: Gallimard, 1997. 57-77.

Derrida, Jacques. "L’Anti-Macias : Moi, l’Algérien de Jacques Derrida." http://www.lematindz. net/news/373-lanti-macias-moi-lalgerien-de-jacques-derrida.html. Le Matin d’Algérie, 21.11. 2007 (18 December 2019).

Diner, Dan. Gegenläufige Gedächtnisse. Zur Geltung und Wirkung des Holocaust. Göttingen: Vandenhoeck \& Ruprecht, 2007.

Diner, Dan (ed.). Enzyklopädie jüdischer Geschichte und Kultur. Stuttgart: Metzler, 2011.

Prenowitz, Eric. "Deconstruction.” https://brill.com/view/package/ejhb Encyclopedia of Jew ish History and Culture Online. Ed. Dan Diner. 2018 (18 December 2019).

Rimmon-Kenan, Shlomith. Narrative Fiction. Contemporary Poetics. New York: Routledge, 2005.

Stevens, Christia. “Hélène Cixous, auteur en 'algériance'." Expressions maghrébines 1 (2002): 77-91.

Zepp, Susanne, and Natasha Gordinsky. Kanon und Diskurs: Über Literarisierung jüdischer Erfahrungswelten. Göttingen: Vandenhoeck \& Ruprecht, 2009. 
